\title{
Embryo research barred from federal funds
}

Washington. In a move that seems destined to cast a new chill over research on human embryos in the United States, President Bill Clinton last week signed into law a ban on US government funding of such research, a concession that formed part of a package aimed at averting a further shutdown of parts of the government.

The ban was inserted by Republicans in a temporary spending measure passed by the House of Representatives on Thursday (25 January), and by the Senate on the following day. The bill, which was signed by Clinton the same day, funds those departments and agencies that still lack permanent 1996 funding until 15 March.

The ban on funding for embryo research, however, which had been dropped from the bill during earlier negotiations, will apply to the end of the 1996 fiscal year on 30 September. It is thought to have been reinserted by Republican negotiators in order to pacify those in their ranks who had softened their position on a separate, anti-abortion, provision. "It was a sweetener for the pro-life crowd," admits one Republican staff member.

In practice, the ban will not halt any current research, as none is being funded by the government. But it reduces the chances that the National Institutes of Health (NIH) will try to initiate embryo research in the next fiscal year, despite the recommendations of an expert panel which concluded in

\section{Shot in the arm for medical policy body}

Washington. A US health research agency whose budget faced the threat of a 60 percent cut by Republicans in the House of Representatives has become an unwitting, if qualified, beneficiary of Washington's current budget impasse.

The proposed 1996 budget for the Agency for Health Care Policy and Research (AHCPR), which carries out research aimed at improving the quality and efficiency of health-care in the United States, was reduced last August by Republicans in the House of Representatives to $\$ 66$ million from its level of \$159.3 million in 1995.

But under several temporary spending measures that have served since October to keep unfunded parts of the US government functioning, AHCPR is being funded at a level equivalent to $\$ 119.5$ million - 75 percent of its 1995 budget. The most recent stop-gap measure, signed by President Clinton last week, continues this funding level through 15 March, when nearly half of the 1996 fiscal year will be over.

This turn of events has angered the Republicans responsible for proposing the original funding reduction, who claim that the agency, best known for its development of clinical practice guidelines, duplicates the work of private medical associations and researchers.

"I'm going to do everything I can to get them off that [ $\$ 119.5$ million] number in the next continuing resolution," says Sam Johnson (Republican, Texas), author of the 1995 amendment that cut the agency's funding to $\$ 66$ million.

Johnson argues that the agency is trying to micro-manage US doctors and hospitals from Washington. "No one has yet told me what they do for America that's good," he says.
The agency's work has also angered some medical pressure groups. The Republicans had been supported in their attempts to cut the budget by the Center for Patient Advocacy, in which a number of spinal surgeons are active. This group disagrees with AHCPR guidelines on lower back pain which claim that surgery is usually unnecessary if the pain lasts less than three months (see Nature 377, 379: 1995).

AHCPR research also angered cataract surgeons three years ago by concluding that surgery was not always the best treatment for cataracts.

But officials from the agency defended its mission vigorously at a meeting of its national advisory council last week. They argue that its work would not and could not be absorbed by the private sector, and that the savings to healthcare resulting from the research of the AHCPR significantly outweigh the dollars that have been spent on funding it.

Officials also complain that the current funding uncertainty is hurting the agency, which has seen applications for its research grants fall by nearly half since its fiscal crisis began last year. The six-year-old agency was left without agreement on an annual budget following the failure of a Senate bill that would have funded it more generously than the House, at \$127.3 million, in 1996.

Clifton Gaus, AHCPR's administrator, future has been left hanging "at a time tant than it's ever been". He points out that the rapid shift in the United States toward managed health-care has highlighted the importance of gathering data on the cost efficiency and clinical effectiveness of medical procedures. $\mathbf{M}$. W. describes it as "ironic" that the agency's when our work is probably more impor-
1994 that, within stringent constraints, research on human embryos is acceptable before the primitive streak appears, at 14 days (see Nature 376, 288; 1995).

Since then, what appears to have been fear of political fallout in the Republicandominated Congress has kept Harold Varmus, the director of the NIH, from enacting the panel's recommendations and thus opening the door to NIH-sponsored embryo research.

The White House argues that Clinton's signing of the budget bill would thus make no difference to the NIH's research plans. "This provision would have no effect on any research currently being funded by NIH," said one official. In 1994 Clinton banned federal funding for research on embryos fertilized exclusively for research purposes. He issued the ban on the same day that the NIH panel concluded that such research was acceptable in limited circumstances.

The new, broader ban has pleased antiabortion Republican legislators. "It will serve a very good purpose in our society because it will honour the sanctity of life," said Jay Dickey (Republican, Arkansas), one of the original authors of the ban.

This was accepted by the House last summer, as part of the bill funding the Departments of Labor, of Health and Human Services and of Education, although a companion bill stalled in the Senate, giving rise to the current need for a temporary funding measure.

But many researchers are dismayed, in particular over the fact that the administration has made a significant concession to conservative Republicans on the issue. "If this persists, there is a danger that some of the important work in the field of embryo research will be delayed. It will impact ultimately on patient care," says Zev Rosenwaks, director of the Center for Reproductive Medicine and Infertility at Cornell University Medical College in Ithaca, New York.

Similarly, Roger Pedersen, a professor of obstetrics, gynaecology and reproductive sciences at the University of California, San Francisco, claims that the ban is "a great loss for millions of Americans suffering from infertility" and that federal support for human embryo research "should not be made a sacrificial lamb for the sake of this political deal".

Although some embryo research, which aims to improve infertility treatment by studying early embryonic development, is still being carried out in the United States, the current ban means that it can be done only with private money. Pedersen estimates that about 300 US centres offer in vitro fertilization procedures, but only about two dozen of these carry out significant research on human embryos.

Meredith Wadman 